\title{
Belgeo
}

Revue belge de géographie

$3 \mid 2001$

Poverty, social exclusion and coping strategies in rural Europe

\section{Alleviating poverty: entrepreneurship and social capital in rural Denmark 1800-1900}

\section{Gunnar L.H. Svendsen and Gert Tinggaard Svendsen}

\section{(2) OpenEdition}

Journals

Electronic version

URL: http://journals.openedition.org/belgeo/15118

DOI: $10.4000 /$ belgeo. 15118

ISSN: 2294-9135

Publisher:

National Committee of Geography of Belgium, Société Royale Belge de Géographie

\section{Printed version}

Date of publication: 30 September 2001

Number of pages: $231-246$

ISSN: 1377-2368

\section{Electronic reference}

Gunnar L.H. Svendsen and Gert Tinggaard Svendsen, « Alleviating poverty: entrepreneurship and social capital in rural Denmark 1800-1900», Belgeo [Online], 3 | 2001, Online since 12 June 2015, connection on 30 April 2019. URL : http://journals.openedition.org/belgeo/15118; DOI : 10.4000/ belgeo.15118

This text was automatically generated on 30 April 2019.

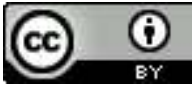

Belgeo est mis à disposition selon les termes de la licence Creative Commons Attribution 4.0 International. 


\title{
Alleviating poverty: entrepreneurship and social capital in rural Denmark 1800-1900 ${ }^{1}$
}

\author{
Gunnar L.H. Svendsen and Gert Tinggaard Svendsen
}

\section{Introduction}

1 The question we raise is why entrepreneurs arise and voluntarily organize larger groups in local areas. This is an important question because voluntary collective good provision in a local area enhances economic growth and alleviates poverty. This question has challenged social sciences for more than three decades. The extreme complexity of this question has motivated us to choose an economic approach. Why? To establish a simple and parsimonious starting point for our discussions. In other words, we start by assuming that group action is economically rational. As shown in the next two sections, this approach is forcefully parsimonious. We know from Mancur Olson's seminal work, The Logic of Collective Action (1965), that it does not pay an individual to provide collective goods voluntarily, if the individual economic gain from doing this is negative (see also Mueller, 1989 and Svendsen G.T., 1998). Thus, as argued in the section called "Entrepreneurship", it does not pay an individual in larger groups to act as entrepreneur and facilitate local collective action, because individual costs from doing so are higher than the individual benefits from acting. Still, everyday observations and the empirical evidence presented in the section on "Entrepreneurs in rural Denmark 1800-1900" tell us that larger groups do organize and that entrepreneurs in the form of group leaders do exist. How can this paradox be explained? Why do we find entrepreneurship within larger groups? This paradox shows that other than economic incentives are important to the economic development of local areas and there is a strong need in literature to fill this gap (see Green and Shapiro, 1994).

2 Cross-disciplinary human science research has approached this problem focusing on the social aspects of the economic transactions (Granovetter, 1985; Coleman, 1994). However, 
in our opinion, the overall theoretical framework of such investigations could be further strengthened by introducing the concept of social capital. In contrast to conceptual cousins such as micro-oriented terms as "network" and "entrepreneurship" (to which social capital should be regarded as a supplement and not a replacement), the notion of social capital can be applied - and has been applied - at both micro-, meso- and macrolevels. This means that the possibility for consistent trans-national comparisons is enhanced. Moreover, as sociologist James Coleman (1994, p. 175) has argued, social capital is a fruitful term to use, because it closely links the economists' word "capital" to the social scientists' key-notion "social" - a point we shall return to. In this way, by including in this very direct way both the economic and cultural sphere, social capital promotes a holistic understanding of collective goods provision processes.

Our contribution is precisely to suggest that the presence of a social glue in the form of social capital - defined as regular face-to-face, co-operative relations - may explain the paradox of collective good provision (see Coleman, 1988a and Putnam, 1993a, 2000). As we argue below, social capital may be built locally as an outcome of innovations in organization ("the rules of the game") and then foster entrepreneurship, which again may lubricate collective action. This theory seems to be confirmed by empirical evidence from rural Denmark 1800-1900.

\section{Collective good provision}

Let us first define what we mean by a "collective good". The relevant decisions and consequences in the local area from having entrepreneurs initiating collective actions are "collective" or "public" goods.

5 A pure public good is traditionally defined by two conditions. First, non-excludability which means that exclusion from consuming the good is not feasible. It is not necessary that exclusion should be technically impossible, only that it is uneconomic. Second, jointness of supply, that is, making a good available to one individual means that it can be supplied to others as well. There is no crowding effect. This definition is consistent with Samuelson's pure collective good which is a good such that additional consumption of it by one individual does not diminish the amount available to others (Samuelson, 1954, p. 387. See also Sandler, 1992; Mueller, 1989 and Hardin, 1982).

6 The abatement of global warming is a rare example of a pure public good because it fulfills both conditions. It is not possible to exclude anyone from enjoying the benefits of avoiding the greenhouse effect and this abatement is independent of the number of people benefitting from it. So, no matter the number of world population, everybody will benefit from avoiding a global catastrophe. International security is another example.

7 However, it is not easy to think of other pure public goods. First, people may be excluded, for example from living in an area with less acid rain or from using a highway. For example, when exclusion is possible - as passing a bridge or producing electricity - then the supply may just as well be undertaken by private firms as by the public, i.e. the state. Second, if too many people consume it (crowding), it will alter what is left, for example "free land" in the Wild West, police and court systems, fire protection, swimming-pools. Imagine for example the ancient case of a castle wall where everybody living inside cannot be excluded from the collective good of protection against roving banditry. There is only room for a certain number of people inside the walls. However, this and other 
"impurities" still represent common goals and are similar to pure public goods over some range. In the literature, such non-excludable goods are called either common, public or collective goods. Here, we prefer the term "collective good" for two reasons. First, as a term where jointness is not a necessary attribute of a collective good. Collective or common simply means that no one in the group is excluded from the benefit. So only the first condition of non-excludability is met. Second, by using this term, we also avoid any confusion, as the term "public" seems to suggest, that only the state can provide the good. However, private goods are often provided collectively for non-economic reasons. Well known cases are those of health services, libraries, bus services, electricity, telecommunication or railways. Such non-collective goods (which are both excludable and without jointness of supply) can always be provided by private enterprise.

Collective action simply means group action. It is relevant in our context whenever two or more individuals are involved, and it serves the interests of the individual better than individual action. Any collective action will fundamentally provide an inseparable benefit for any member of the group. So, in its most abstract sense, collective action is to be found whenever the grouping of two or more individuals is needed for accomplishing a goal. With this wider definition, all collective goods are covered. The achievement of any common goal (in relation to a specific group) in a local area means that a collective good has been provided for all members in that group. In the section called "Social capital ", we return to actual examples of collective good provision in rural Denmark due to the work of local entrepreneurs.

\section{Entrepreneurship}

9 However, it does not follow that perfect consensus, both about the desire for the collective good and the most efficient means of getting it, will always bring about the achievement of group goal. Mancur Olson's seminal contribution from 1965 is that rational, individual behaviour does not lead to rational group behaviour. Even if the total benefits by far exceed total costs for achieving a common goal, it does not logically follow that collective action takes place.

This point broke with traditional group theory which was based on the degree of consensus. An individual will voluntarily act in support of common group interests and values as a logical consequence from the widely accepted premise of rational self-interest. Exceptions to this rule occur when the leadership is ignoring the group interests and, due to asymmetrical information (leaders know more than the rest of the group members), is serving other ends (Olson, 1965, p. 5).

11 In other words, prior to Olson (1965), groups were simply viewed as voluntary organizations furthering their common interests. But this is not so, says Olson. Rational individual behaviour does not lead to rational group behaviour! Olson formulates it as follows:

(..) rational, self-interested individuals will not act to achieve their common or group interests [1965, p.2]

12 This means that even though the aggregate gains that a local group attains from a collective good greatly exceed the total costs of that action (and thereby enhances prosperity), it does not follow that the action will occur: Individual rationality does not lead to collective rationality. David Hume is the first to treat the collective (public) choice 
problem in an academic way. In his A Treatise of Human Nature from 1739 he writes that when men have protected themselves against each other's weaknesses and passions - by the execution and decision of justice - they "begin to taste at ease the sweets of society and mutual assistance" (Hume, 1984, p. 589). He exemplifies this situation by looking at two farmers that may agree to drain a swamp which they own in common. They know each other's mind, and failing means abandoning the project. Hume then went on to observe that it is indeed impossible that a thousand persons should agree on any such action, "it being difficult for them to concert so complicated a design, and still more difficult for them to execute it; while each seeks a pretext to free himself of the trouble and expense, and would lay the whole burden on others" (Hume, 1984, p. 590).

This brings us back to Mancur Olson's main point that individual rationality does not necessarily lead to collective rationality. Why is it so? Let us take a closer look at the distribution of costs and benefits in a group. Say that the total value of draining the swamp is $\$ 1$ million to the group of farmers, and that the total cost of drainage is $\$ 100,000$. Further assume that the value of drainage, if provided, would be shared equally among all the members.

If the group has 2 farmers, they share the total benefit equally and each member will experience a benefit valued at $\$ 500,000$. Since each individual member's net benefit from providing the good is positive in this case $(\$ 400,000)$, the good will now be provided even in the absence of organization. If the group has 1,000 farmers, each farmer would receive an individual gain of $\$ 1,000$. Although the group as a whole would stand to get benefits worth ten times the amount of money invested in draining the swamp, the net benefit to any individual member who chooses to provide the good on his or her own is clearly negative. In the absence of organization, the collective good will therefore not be provided. As such, the link between individual rationality and group rationality depends on the individual net benefit from contributing to the collective good. Table 1 resummarizes this logic.

Table 1. Collective Good Provision.

\begin{tabular}{|l|l|l|}
\hline & $\mathbf{2}$ farmers & $\mathbf{1 0 0 0}$ farmers \\
\hline $\begin{array}{l}\text { Total gain } \\
\text { Individual gain }\end{array}$ & $\begin{array}{l}\$ 1 \text { million } \\
\$ 500,000\end{array}$ & $\begin{array}{l}\$ 1 \text { million } \\
\$ 1,000\end{array}$ \\
\hline Total cost & $\$ 100,000$ & $\$ 100,000$ \\
\hline Individual net gain & $\$ 400,000$ & Negative $(\$ 1,000-\$ 100,000)$ \\
\hline
\end{tabular}

In other words, Olson (1965) suggests that in the small group of two farmers, both will act as entrepreneurs and will voluntarily provide the collective good on their own, because they both get a positive economic net gain from doing so. In contrast, in the larger group of 1,000 farmers no one will act as entrepreneur on their own and start organizing the group, reaping the aggregated economic benefits for the group (or local society) as a whole, because the economic net gain is clearly negative. Although mobilization of these larger groups is difficult and takes time, it happens. Olson explains the presence of entrepreneurs and group mobilization in larger groups by the phenomenon of chance. Only when the right leadership and the right circumstances are present, a group may develop (Olson, 1982). E.g., he gives an illustrative example of a young union 
entrepreneur, Jimmy Hoffa. Hoffa was one of the workers in an unorganized warehouse in Detroit. On a hot summer day, a large shipment of strawberries - that would soon spoil arrived. Hoffa then persuaded his co-workers to strike. The employer found it better to accept Hoffa's demands than to lose his perishable cargo (Olson, 1982, p. 38). However, this ad hoc explanation offered by Olson is clearly unsatisfactory, thus leading us to alternative explanations.

\section{Networks, entrepreneurship and life-modes}

The behavioural assumption underlying Mancur Olson's work and that of other economists is that man will pursue private interests and not those of the public or the common. The assumption about human behaviour is as such harsh and simple: Only selfinterest matters! No moral is involved and each agent will unscrupulously try to maximize his own net benefits. For example, moral and ideology play no role. As Deng Xiaoping once put it: It does not matter what colour the cat is, as long as it can catch the mice! Thus, concerning income, the rational preference of man is to maximize private income in monetary terms and, next, to purchase a number of ranked goods in the market. In this way, economists focus on the agent with given preferences.

In contrast, we will view preferences as unstable, because social interaction may create norms and values which heavily guide the actions of the individuals so that individual action is typically reproduced due to the given structure.

This is reflected in the so-called F-connection (family, friends, and firms), which was introduced by economist Yoram Ben-Porath (1930), as well as in sociologist Granovetter's $(1985,1995)$ notion of the "embeddedness" of economic transaction sin differing cultural contexts. For example, in an American context, Granovetter has shown that getting a job normally requires that the actor uses his or her social network in the form of friends, acquaintances and the like. In this way, Granovetter explains, getting a job depends more on using the resource of "weak ties" rather than that of "strong ties", that is, kinship based relations $(1973,1974)$.

Economist Bengt Johannisson's research on the networking of community entrepreneurs closely links to Granovetter's findings (see for example 1987, 1989, 1997).Here, the "network metaphor" is used to bridge between "social and economic dimensions of human conduct", while "entrepreneurship" is regarded as "an act of creation" and "small business as a way of life, that is, as phenomena beyond rational economic behaviour" (Johannisson and Mønsted, 1997, p.109). In this way, Johannisson and Nilsson (1989, p. 18) has documented that, in contrast to traditional entrepreneurs that "reorganize resources", entrepreneurs networking in local communities (i.e., "contextual" entrepreneurs)"reorganize values".

Generally, a lot of research in the Scandinavian countries applies a socioeconomic approach, aiming to interlink the economic with the non-economic - not in the least in connection with investigations in networking and entrepreneurship (Johannisson and Mønsted 1997). Moreover, in the beginning of the 1980s, a group of Danish ethnologists (Christiansen, 1982; Møllgaard, 1984; Højrup, 1983, 1989) developed the concept of "lifemode", referring to the "totality" of a practice and a world view belonging to a distinct group (i.e. Danish peasants). For example, Thomas Højrup (1983, p. 17) has suggested to "construct the concepts of several distinct life-modes, which are thebases 
for [group] practices and ideologies and which place their own distinct demands on social institutions and social organization as a whole".

\section{Social capital}

21 In a similar way, Coleman (1994, p. 175) uses the term "social capital" in an attempt to fill a "lacuna in social and economic theory". As has already been mentioned, Coleman (ibid.) here argues that the two words denote a useful linkage inthat the economics term "capital" implies a resource that facilitates production, "but is not consumed or otherwise used up in production", while the social scientists' notion of "social" refers to "aspects of social organization, ordinarily informal relationships, established for noneconomic purposes, yet with economic consequences" (see also Svendsen and Svendsen, 2000, p. 73; Paldam and Svendsen, 2000; Paldam, 2000). Furthermore, applied to empirical data Coleman (1988b, p. 388ff, 1988a, p. 116ff.) sees social capital as a public good, that is, a product that also benefits other persons than the producer himself, including persons who are unknown to the producer. For example, it can be statistically documented that the production of human capital in schools is highly facilitated, when pupils possess social capital in the form of strong networks consisting of family, friends and neighbours, who know each other and meet regularly, thus ensuring shared norms and social control. This Coleman has termed "closure" (1988b, p. 386ff.) ${ }^{2}$. At the same time it follows that, if a key-person in the local production of social capital moves from a community (for example, a parent of one of the school children), other persons than this person will feel the losses by the "severance" of closure-based relations(1988b, p. 389).

This should confirm the importance of social capital as a collective good - but why the focus on entrepreneurship and rural communities? Because in local areas people have rich possibilities of getting to know each other and meet regularly and so prepare the ground for social incentives facilitating group action and the realization of collective goods. However, as has already been stressed, the provision of collective goods necessarily implies that the rural community in question is based on non-excludability or, in other words, that the inhabitants generally tend to pursue "integrating" and not "excluding survival strategies" and thus are promoting the spread of social networks rather than restricting them so as to include only a circle of privileged group members (Meert, 2000, p. 328).

23 Recalling the case of the draining of as wamp, this suggestion only holds for larger groups where social action with most people is possible, such as a local group consisting of 1,000 individuals (like the 1,000 farmers, see Table 1). Very large groups having millions of members (for example all citizens in a country) are not fertile ground for the use of social incentives and thus, of the building of social capital. Therefore, only the focus on larger groups is relevant when discussing entrepreneurship and social capital in the context of local areas and poverty alleviation. This focus is also justified in an earlier paper where we showed how local dairy production in Denmark probably encouraged entrepreneurship and the initiation of larger local group organization around this production (Svendsen and Svendsen, 2000). Note that very large groups without regular social interaction among most individuals are not relevant in this setting. 


\section{Entrepreneurs in rural Denmark 1800-1900}

It was not only the increasing number of associations that facilitated the emergence of a strong, rural civic society, but also the diversity of their functions. Thus, knowledge and organizational training were transmitted through economic and cultural associations ranging from insurance associations, savings banks, production associations, agronomist and political associations to youth associations, gymnastic clubs, rifle clubs and temperance societies - all of them closely related to shared buildings financed and raised by the local communities themselves, such as free schools, folk high schools, free churches, teacher training colleges, agricultural colleges, religious meeting houses and drill-halls. Ultimately, this process led to an extremely active, rural population, taking care of local and regional political, economic and cultural functions and thus - without any state interference -gradually improving their own living conditions, which at about 1800 had been extremely poor (Svendsen G.L.H., 2001).

27 At the local level, the historical sources indicate that such civic initiative was primarily due to the activities of certain individuals engaged, as it seems, in every single associational innovation in their communities. Obviously, these charismatic entrepreneurs or ildsjoele - "souls of fire"- acted from a blend of economic, idealistic and purely personal motives, often not realizing that their strong commitment was a public good, ultimately leading to common benefits for all the members of the local society both economically and culturally. As we shall see, an excellent example ere is the men behind the Danish Co-operative Movement.

Moreover, studying the historical evidence carefully makes it clear that from the 1840smost of these local entrepreneurs developed into organizers of local as well as regional networks of associations, that is, specific "associational milieus" consisting of a variety of associations sharing the same political and/or religious ideology and, typically, with an overlapping membership. The regular face-to-face interaction resulting from such a network of associations- voluntarily established and maintained by local 
entrepreneurs - led to a general strengthening of mutual trust and common norms in the rural districts, thus "lubricating" society to use an expression from Putnam (1993b, p. 2).

However, due to major innovations in organization, association building rapidly increased and finally culminated in a Danish co-operative movement from the mid1860s. In this way, association building turned into social capital building fostering entrepreneurship and the provision of collective goods and, thus, improving material as well as immaterial life conditions of the Danish rural population. These collective, that is non-excludable, goods were provided by local entrepreneurs orildsjele, whose personal, economic net gains were clearly negative, both compared to the amount of time and energy spent, but, especially, compared to the benefits they provided their communities in the form of the strengthening of shared norms and, ultimately, of enhancing economic growth. This is in accordance with James Coleman, who talks about "underinvestment in social capital" due to the fact that "the actor or actors who generate social capital ordinarily capture only a small part of its benefits" (1988a, p. 119; see also 1988b, p. 389; 1990, p. 317ff.).

\section{Philanthropic entrepreneurs}

From about 1780, a feudal Denmark based on a subsistence economy was gradually transformed into a liberalistic society based on a modern monetary economy. Agricultural reforms had made it profitable for landlords to allocate land to peasants, who in great numbers moved from the villages to their new dwellings. In this way, the reforms promoted a demographic transition that, evidently, already was initiated in the $18^{\text {th }}$ century.

31 The need to finance such large-scale enclosure of land and the following demographic transformation immediately led to serious cash-flow problems. Thus, the poor liquidity among the peasants necessitated that the state as well as landlords, merchants and private persons guaranteed the sums needed. However, as expressed by a famous Danish historian, the peasants were often exploited by professional moneylenders, charging "bloody interests" (Hertel, 1917, p. 18).

Consequently, landlords and peasants together were increasingly seeking new forms of economic co-operation in the rural districts in order to secure economic and social stability. In this context, the kingdom's first credit and savings bank was established in 1810 by Count F. A. Holstein, who, strongly influenced by German philanthropy, adopted the idea from Prussia (Hertel, 1917, p. 19). Of an equally moralistic character were the rural district savings banks, established during the 1820s, inviting the ordinary rural population to prevent personal calamities by lifelong money saving. During the 1840 s, there was an increase in the number of savings banks and private joint stock companies, offering the peasants loans at low interests.

Even cheaper, however, were the loans offered by the new credit associations from about 1850. The latter introduced the idea of shared economic responsibility in the rural districts, an organizational strategy which was to become one of the cornerstones in the founding statutes of the cooperative dairies in the second half of the century. 


\section{The Danish co-operative movement}

The early philanthropic associations were to form the basis of a regular co-operative movement within Danish agriculture - a movement, which quickly evolved during the second half of the 19th century. In this period, the Danish peasants established a multitude of co-operative associations, ranging from co-operative wholesale societies from 1866, co-operative dairies from 1882, co-operative fodder and fertilizer purchasing associations from 1883, and co-operative meat packing plants from 1887. The decisive innovation consisted in the specific organizational structure of these associations, strongly promoting co-operative networks of an inclusive nature and thus the accumulation of beneficial social capital. Right from the beginning, this organizational structure was institutionalized in the standard founding statutes of the co-operative association.

The initial idea came from England. In1844, in Rochdale near Manchester, a group of weavers founded the first co-operative wholesale society in the world, that is, a sales and purchasing company owned by the members themselves. About twenty years later, two friends living in the village of Møgeltønder in the southern part of the Jutland peninsula Doctor F. F. Ulrikand H. C. Sonne, a priest - discussed the Rochdale principles. Ulrik had been familiar with these ideas for some time and now he provoked passionate interest from Sonne (Ravnholt, p. 30). In various ways, these philanthropically minded men were trying to alleviate the conditions of the poorest part of the population by establishing a wide range of charitable organizations and institutions in the area (Dollerup, 1966, p. 34ff.).

Figure 1. Danish parish savings banks 1865-1914, deposits in million DDK.

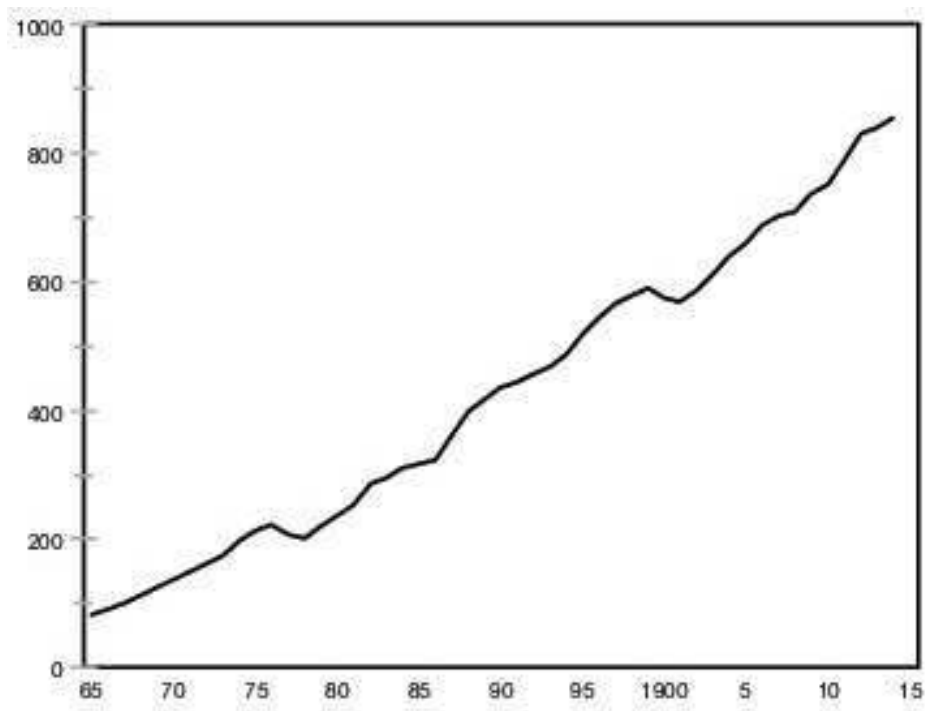

SOURCE: BLINKENBERg NIELSEN, 1950, PP. 172-73

During the first part of the $19^{\text {th }}$ century, then, the finance market was to a still lesser degree dominated by the state and by the philanthropic and liberal-thinking landlords, thus giving place for financial institutes owned by the peasants themselves. Especially during the 1850s and 1860s, with the foundation of a great number of local agricultural savings banks, this tendency became clear. In this way, the rural financial institutes and 
similar peasant owned institutions such as health, cattle and fire assurance associations should be seen as a basic element in the process of self-organization, leading to an increase in economic and political independence among the population in the Danish countryside (Bjørn, 1982, p. 97).

The competition between rural and urban savings banks should be seen in this light. So we see that, at the micro level, the majority of the peasants who had been leading figures behind the first savings banks, situated in the provincial towns, now left the bank committees to establish new local, rural savings banks, called parish savings banks (Blinkenberg Nielsen, 1950, p. 11). Thus, these local, parish entrepreneurs or souls of fire, ildsjele, taking an active part in the conflict between rural and urban Denmark, promoted a decentralized co-operative structure in the countryside.

However, after the defeat by Prussia in 1864 and the consequent loss of the southern part of Jutland, Ulrik and Sonne, being glowing patriots, were forced to leave the region, though they continued their entrepreneurial activities in close co-operation with other kindred spirits. So, in Copenhagen, Ulrik started a building association for shipyard workers in 1865 , while Sonne established the first Danish wholesale society in the small borough of Thisted in 1866.

Obviously, the great success of this first wholesale society in Denmark was due to Sonne's vast insight into the original organizational principles used in the English co-operative wholesale movement - a knowledge he had obtained partly during several study tours, partly by reading all the English literature about the subject he could get. All this is documented in a book, Sonne wrote in 1867, the year after he had founded his wholesale society (see also Dollerup, 1966, p. 50). Drawing on practical experiences from the wholesale society in Thisted, he here propagated the "laws from Rochdale", that is, the founding statutes he himself had successfully implemented in a Danish local community (Sonne, 1867, p. 4ff.). In this way, promoted by key-principles such as allocation of profits due to the amount of purchases done by the members ( $\$ 2$ and $\$ 6$ ), shared economic responsibility (\$3), open membership (\$4) and democratic decision- making (\$5), the purpose of the wholesale society in Thisted (\$1) is "in perfect accordance with the Rochdale laws to establish a foundation by subscriptions voluntarily paid by the members, in order to allow them to purchase more profitably the necessities of life" (Sonne, 1867, p. 5). However, this objects clause Sonne only recognized as a means to fulfill the overall and "true" purpose, namely on the basis of an alleviation of economic poverty to "raise the lower, more dependent and suppressed part of the population to a higher social level, morally as well as intellectually, that is, to a more decent position in society" (Sonne, 1867, p. 5).

If the founding statutes did not fully lead to this idealist goal - at least, not in Sonne's lifetime - they actually did offer an organizational structure apt to increase the material welfare of the poor majority of the Danish population - not at least in the countryside, where the peasants followed Sonne's advice and formed their own wholesale societies to protect themselves against economic exploitation. In this way, and especially from the mid-1880s, the number of wholesale associations rapidly increased to approximate 850 by the turn of the century and - which appears quite remarkable in an international context - all of them established in local rural communities, apart from a few exceptions (figure 2). 
Figure 2. Danish wholesale societies 1866-1900.

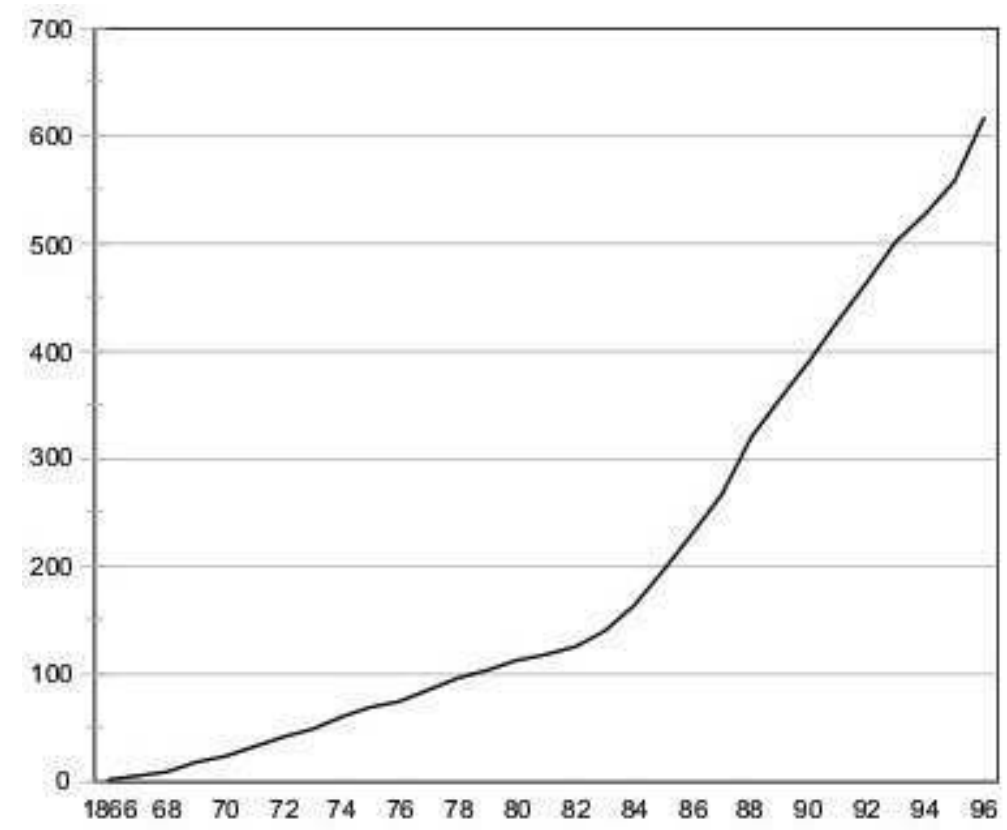

SOURCE: CHRISTENSEN, 1985, P. 200

However, even more important as it seems, the founding statutes of Sonne's co-operative wholesale society were to be widely applicated within the agricultural sector, introducing important "rules of the game" that would strongly enhance co-operation among Danish farmers as well.

Especially within the so-called Danish cooperative dairy movement from 1882, the cooperatively based form of organization was further elaborated, juristically as well as in practice, to fit the norms and culture of the Danish rural population. It was in the village of Hjedding near Varde, in the western part of Jutland, that a group of entrepreneur farmers founded the first cooperative dairy. In his memoirs, dating from 1901, one of the main promoters of the project, farmer Niels Kristensen, writes the following about the initial discussions:

During the negotiations, a general sentiment evolved so as to make preference for collecting the milk instead of the butter (...). To be able to prepare the milk in one place, it was necessary to build a dairy. This, however, gave rise to another problem, since some of the farmers had no wish to build a dairy with others, while they consented to selling their milk to the dairy. In this way, without anybody really knowing it, the negotiations went in the direction of the realization of that, as it later on was to become, widespread and magnificent cooperative idea: that everybody who joined the dairy should be allocated profits on the basis of the amount of milk he delivered [translated from Manøe Hansen, 1972, p. 13].

Immediately after this meeting, some of the peasants joined to write the contract of the association. Overall, their articles reflect all the ideas of Sonne and the English wholesale society movement, stressing principles such as allocation of profits in proportion to the amount of milk delivered by the members, shared economic responsibility, open membership, and, not least, democratic decision-making, which here was further specified as "one man one vote" at the yearly general assembly, where all major decisions regarding the dairy should be taken (for more details, see Svendsen and Svendsen, 2000, 
p. 76ff.). During the next couple of months, the building of the dairy in Hjedding took place, led by the committee members themselves (Kristensen in Manøe Hansen, 1972, pp. 16-17). And in June 1882, dairy production started.

Less than 10 years after this event, the "Hjedding model" had been spread to every single corner of the country. Looking at the figures, the economic success appears evident. In 1890, one third of all Danish farmers delivered milk to one of the roughly 700 cooperative dairies. Consequently, the Danish export of butter increased from 12.5 million $\mathrm{kg}$ in 1880 to about 90 million at the beginning of the new century, while the export of milk increased from 200 litres to about 600,000 litres in the same period (Bjørn, 1982, p. $21,552,561)$.

Primarily, this success originated in the organizational structure behind the cooperation, that is, in the founding statutes of the model dairy of Hjedding. First, all over the country, such a contract - the written rules of the game - involved an extraordinary compromise between two, conflicting groups, the well-to-do farmers and the small-holders. Using the Hjedding model as a concrete tool, these two groups now began to co-operate on equal terms. The Hjedding model made such "impossible" co-operation possible, exactly by stressing the shared, economic interest of all farmers. So we understand, why $\$ 1$ of the founding statutes from Hjedding in detail advocated this shared interest by focussing on cash payment to the members in proportion to the amount of milk delivered by each individual during a certain period of time ${ }^{3}$. In particular, this paragraph satisfied the well-to-do farmers. Moreover, in order to satisfy the small-holders as well, the statutes secured democratic decision making (\$12). Thus the farmers voted "according to heads and not according to cows", as it was formulated. Everybody, high and low, was equal ${ }^{4}$.

In this way, written rules of the game secured the formation of bridging social capital. First, clear rules of the game secured a formalization of co-operation, which included the possibility of sanction towards those members who violated the rules, all the peasants had agreed upon (\$9). In this way, any farmer who diluted the milk by adding water, used wrong fodder for his cows, or in other ways tried to cheat the others would run the risk of exclusion.

The milk must be delivered to the dairy in a pure and non-adulterated condition. Milk from sick cows must not be delivered (...). If it can be documented that the milk delivered by a supplier has been adulterated, either by addition of water or other mixtures, or if foamy milk is delivered, if the milk of sick cows has been added, or if the pails are dirty - in such cases, the supplier is excluded from the association and will be fined an amount of [etc.] [translated from Manøe Hansen, 1972, p. 34]. 
Figure 3. Danish co-operative dairyworks 1882-90.

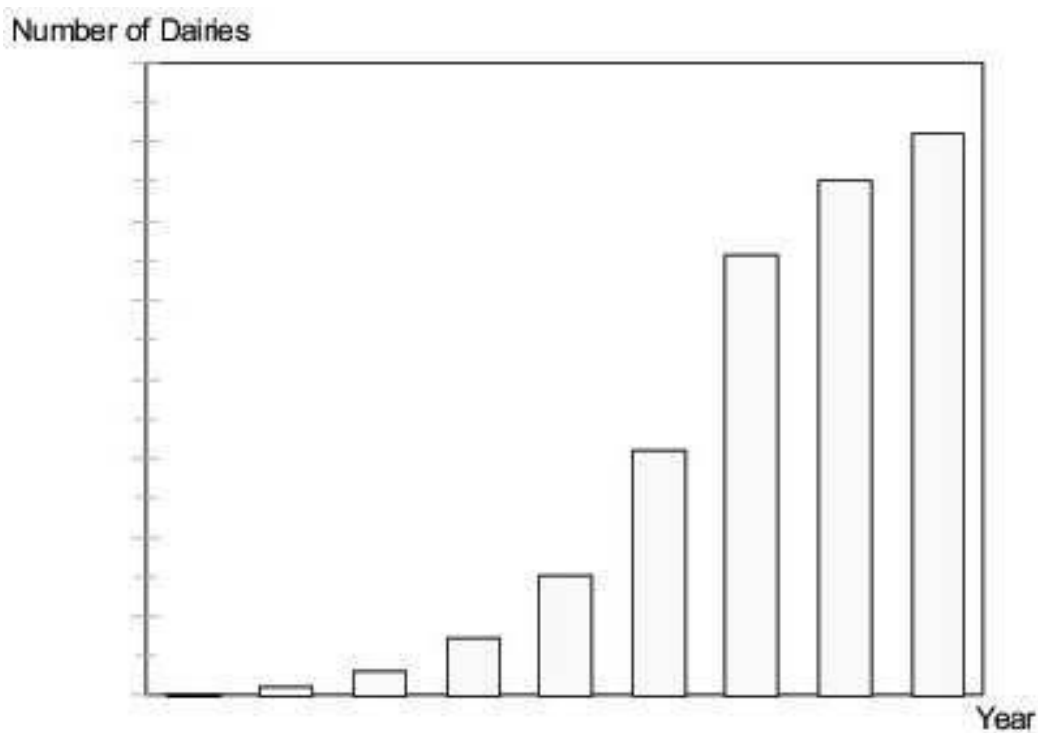

SOURCE: BJøRN 1982, P. 85

Second, as farmers got used to following the clear, written rules of the game, the formalized framework for co-operation became "naturalized", that is, diffused into informal exchange as well. In this way, cooperation according to the rules of the game, implying collective good provision, became a natural way of acting, normal behaviour which the peasants did not even reflect upon anymore. The rules were internalized. They became culture.

Figure 4. Number of pupils in Danish rural folk high schools 1865-1900.

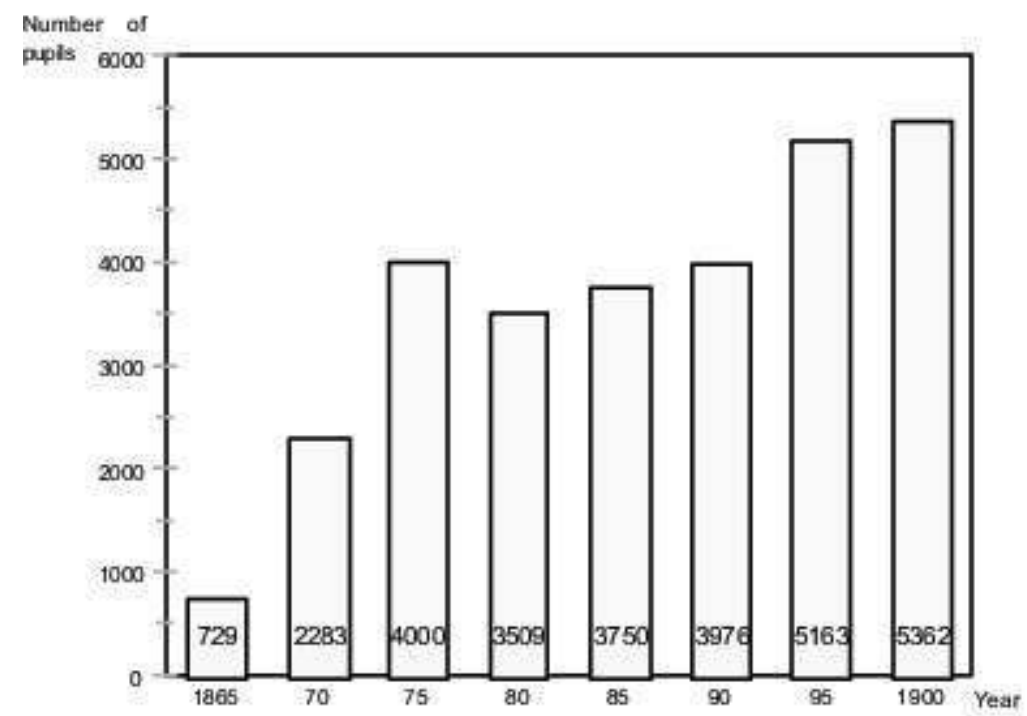

SOURCE: RøRDAM, 1983

Right from the beginning, this process was certainly not facilitated by the Danish state in fact it took place in spite of the state. So, until the end of the 1880s, the Danish government - conservative and anti-socialist as it was - did nothing to encourage the 
foundation of co-operative dairies. On the contrary, both the state and the agricultural organizations were often "downright negative" in their relation to the dairies (Bjørn 1982, p. 80). Consequently, the co-operative dairies were formed through a bottom-up process, by local entrepreneurs primarily, and in accordance with the cultural traditions and norms of the local community, that is, with a high degree of local embeddedness (Bjørn, 1982, p. 119). As formerly had been the case with the wholesale companies, the farmers financed their dairies themselves, making use of the local, parish savings banks, just as they paid for all professional assistance needed, if unable to accomplish these various tasks themselves (Bjørn, 1982, p. 100, see also Paldam and Svendsen, 2000).

In this way, the outcome of entrepreneurial activities and the building of stocks of social capital was first of all a significant increase in economic growth in former poor, rural areas. Second, as has already been indicated, the outcome was a general "lubrication" of mutual relations within the local communities, including cultural life. It is in this light we should see the formation of a multitude of cultural institutions during the second half of the $19^{\text {th }}$ century, such as folk high schools, religious meeting- houses, drill-halls - all of them enhancing the accumulation of other capitals in rural Denmark other than economic, such as human capital. This again strengthened the "recruitment" of new generations of local entrepreneurs providing collective goods and, at the same time, carrying on the building of beneficial social capital.

This can be illustrated in the following way:

Figure 5. The building of the beneficial social capital.

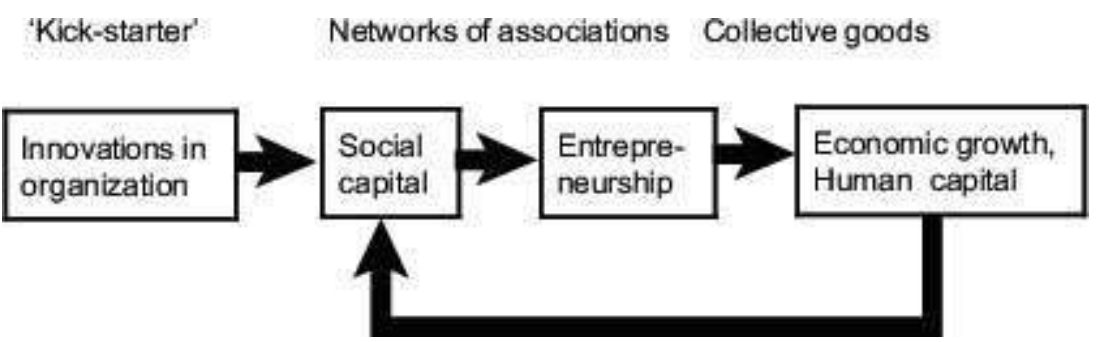

51 As can be seen in figure 5, this development was initiated by innovations in organizational structure ("rules of the game"), acting as a "kick-starter" for the formation of networks of associations and stocks of beneficial social capital, that is, bridging social capital, fostering local entrepreneurs all over the country to provide collective, non-excludable goods. Consequently, this development was not only to the profit of the single, local community but to the benefit of the whole nation. As showed in the figure, this again contributed to the accumulation of social capital and the recruitment of new generations of entrepreneurs, etc.

\section{Conclusion}

The question we raised was why entrepreneurs arise and voluntarily organize larger groups in local areas. This question was important because voluntary collective good provision in a local area enhances economic growth and alleviates poverty. We argued that a gap in economic literature exists. If the individual economic gain from providing a collective good is negative, it does not pay an individual to act and organize. Still, larger groups actually do organize in local areas even though the individual net gain is clearly 
negative. This paradox cannot be explained in strict economic terms. Thus, in an attempt to fill out this gap in literature, we offered another solution to this paradox, namely the presence of social incentives called "social capital". Regular face-to-face interaction presumably encouraged co-operative relations among larger groups in local areas. Such relations, we argued, would be initiated (kick-started) by innovations in organizational structure in the form of clear, written rules of the game.

This theoretical suggestion seemed to be confirmed by empirical evidence from rural Denmark 1800-1900. Here, it was shown, the formalization of co-operation included sanctions, most prominently exclusion from the group, towards those members who violated the rules. Gradually, as farmers got used to follow the written rules of the game, the formalized framework for co-operation became "naturalized", that is, diffused into informal exchange as well. In this way, co-operation according to the rules of the game, implying collective good provision, became a natural way of acting, normal behaviour which the peasants did not even reflect upon anymore. The rules were internalized and turned into culture which again would further speed up the accumulation of beneficial social capital (bridging social capital) and promote the recruitment of future generations of local entrepreneurs. In this way, a good circle of social capital building would be secured. As an outcome of this process, entrepreneurs provided collective goods, contributing to economic growth and education in former poor, rural areas.

\section{BIBLIOGRAPHY}

BEN-PORATH Y. (1930), “The F-Connection: Families, Friends, and Firms and the Organization of Exchange", Population and Development Review, 6, pp.1-30.

BJøRN C. (ed.) (1982), Dansk Mejeribrug 1882-2000, Odense, De danske Mejeriers Faellesorganisation. BLINKENBERG NIELSEN O. (1950), De danske Sognesparekasser 1865-1914, Copenhagen, Sparevirkes Forlag.

CHRISTENSEN J. (1985), Landbostatistik, haandbog i dansk landbohistorisk statistik 1830-1900, Copenhagen.

CHRISTIANSEN P.O. (1982), En livsform på tvangsauktion?, Copenhagen, Gyldendal.

COLEMAN J.S. (1988a), “Social Capital in the Creation of Human Capital”, American Journal of Sociology, 94, pp.95-121.

COLEMAN J.S. (1988b), “The Creation and Destruction of Social Capital: Implications for the Law”, Journal of Law, Ethics \& Public Policy, 3, pp.375-404.

COLEMAN J.S. (1990), Foundations of Social Theory, Cambridge, Massachusetts, and London, England, The Belknap Press of Harvard University Press.

COLEMAN J.S. (1994), "A Rational Choice Perspective on Economic Sociology”, in SMELSER N.J. and SWEDBERG R. (eds.), The Handbook of Economic Sociology, New York, Princeton University Press, pp.166-178. 
DOLLERUP P. (1966), Brugsforeningerne 1866-1896. Sociale, oekonomiske og politiske undersoegelser i de danske brugsforeningers historie fra 1866 til 1896, Albertslund, Det danske Forlag.

GRANOVETTER M.S. (1973), “The Strength of Weak Ties”, American Journal of Sociology, 78, 6, pp.1360-80.

GRANOVETTER M.S. (1974), Getting a Job: A Study of Contacts and Careers, Cambridge, MA, Harvard University Press.

GRANOVETTER M.S. (1985), "Economic Action, Social Structure and Embeddedness”, American Journal of Sociology, 91, pp.481-510.

GRANOVETTER M.S. (1995), "The Economic Sociology of Firms and entrepreneurs", in PORTES A. (ed.) The Economic Sociology of Immigration, New York, Russel Sage, pp.128-65.

GREEN D.P. and Shapiro I. (1994), Pathologies of Rational Choice Theory: A Critique of Applications in Political Science, Yale University.

HARDIN R. (1982), Collective Action. Resources For the Future, Baltimore, Maryland, The John Hopkins University Press.

HERTEL H. (1917), Andelsbevaegelsen i Danmark, Copenhagen, Gyldendalske Boghandel-Nordisk Forlag.

HUME D. [1739] 1984), A Treatise of Human Nature, New York, Penguin Books.

HØJRUP T. (1983), “The Concept of Life- Mode. A Form-Specifying Mode of Analysis Applied to Contemporary Western Europe”, Ethnologia Scandinavica, pp.15-50.

HØJRUP T. (1989), Det glemte folk. Livsformer og centraldirigering, Hørsholm, Statens Byggeforsknings Institut.

JOHANNISSON B. and NILSSON A. (1989), "Community entrepreneurs: networking for local development”, Entrepreneurship and Regional Development, 1, 1, pp.3-19.

JOHANNISSON B. and MØNSTED M. (1997), “Contextualizing Entrepreneurial Networking. The Case of Scandinavia", International Studies of Management and Organization, 27, 3, pp.109-136.

JOHANNISSON B. (1987), “Anarchists and organizers - entrepreneurs in a network perspective”, International Studies of Management and Organization, 17, 1, pp.49-63.

MANØE HANSEN (ed.) (1972), Hjedding Andelsmejeri 1882-1905, Ansager, Ølgod museum.

MEERT H. (2000), "Rural Community Life and the Importance of Reciprocal Survival Strategies", Sociologia Ruralis, 40, 3, pp.319-338.

MUELLER D.C. (1989), Public Choice II, Cambridge, Cambridge University Press.

MØLLGAARD J. (1984), Landbrugets livsformer. Copenhagen, Statens Byggeforskningsinstitut.

OLSON M. (1965), The Logic of Collective Action, Cambridge, Cambridge University Press.

OLSON M. (1982), The Rise and Decline of Nations, New Haven, Yale University Press.

PALDAM M. (2000), “Social Capital: One or many?, Definition and measurement", Journal of Economic Surveys, 14, 5, pp.629-53.

PALDAM M. and SVENDSEN G.T. (2000), “An essay on social capital: Looking for the fire behind the smoke", European Journal of Political Economy, forthcoming. 
PORTES A. (1998), “Social Capital: Its Origins and Applications in Modern Sociology”, Annual Review of Sociology, 24, pp.1-24.

PORTES A. and SENSENBRENNER J. (1993), "Embeddedness and Immigration: Notes on the Social Determinants of Economic Action", The American Journal of Sociology, 98, 6, pp. 1320-50.

PUTNAM R.D. (1993a.), Making Democracy Work. Civic Traditions in Modern Italy, Princeton, New Jersey, Princeton University Press.

PUTNAM R.D. (1993b.), "The Prosperous Community. Social Capital and Public Life", The American Prospect, 13 (Spring), pp.35-42.

PUTNAM R.D. (2000), Bowling Alone, The Collapse and Revival of American Community, New York, London, Toronto, Singapore, Simon \& Schuster.

RøRDAM T. (1983), Fra Andelssamfundets Barndom. En Folkebog, Jelling, Dansk Friskoleforening.

SAMUELSON P. (1954), “The Pure Theory of Public Expenditure”, Review of Economics and Statistics (Nov.), pp.387-89.

SANDLER T. (1992), Collective Action: Theory and Applications, Ann Arbor, University of Michigan Press.

SONNE H.C. (1867), Om Arbejderforeninger. Til Oplysning og Veiledning, Copenhagen, Louis Kleins Bogtrykkeri.

SVENDSEN G.T. (1998), Public Choice and Environmental Regulation: Tradable Permit Systems in the United States and $\mathrm{CO} 2$ Taxation in Europe, New horizons in environmental economics, Cheltenham, Edward Elgar.

SVENDSEN G.L.H. (2001), “Historien anskuet som et kapitalmarked. Selvorganiseringen i de danske landdistrikter 1800-1900”, Fortid og Nutid, 1 (March), pp.23-51.

SVENDSEN G.L.H. and SVENDSEN G.T. (2000), "Measuring Social Capital: The Danish Co-operative Dairy Movement", Sociologia Ruralis, 40, 1, pp. 72-86.

\section{NOTES}

1. We gratefully acknowledge the contributions from the other participants in the ongoing World Bank project on social capital. In particular, we thank Martin Paldam, Henrik Christoffersen, Ann-Marie Gabel and the financial support from the Danish Trust Fund, as well as from the research program, "People in the Agrarian Landscape", under the cross disciplinary research initiative, "The Agrarian Landscape in Denmark 1998-2001", financed by the Danish Research Counsels.

2. Strong social control in groups can lead to the production of negative social capital, that is, network co-operation that is limiting the life possibilities of the members instead of improving them. Drawing on empirical studies of immigrant groups in USA, this has been documented by Portes (1998) and Portes and Sensenbrenner (1993). In his latest book, Bowling Alone, Robert Putnam (2000) in a similar way talks about "bonding social capital" in contrast to (positive) "bridging social capital".

3. "The profit obtained from sale [of cheese and butter] is distributed among the members in proportion to the amount of milk, each has delivered, minus the running expenses of the dairy. The profit from sale of butter is distributed monthly, whereas profit from sale of cheese is distributed once a year. Every day, buttermilk and whey is 
delivered back to the members in proportion to the amount of milk, each member has delivered" ( $\$ 1$ of the founding statutes of Hjedding, translated from Manøe Hansen 1972, p. 33).

4. With the exception of 10-15 percent of all Danish co-operative dairies, which voted 'according to cows and not according to head' (Bjørn 1982, p. 95).

\section{ABSTRACTS}

Why do we find entrepreneurship within larger groups? This question has challenged the social sciences since Olson (1965) showed that it does not pay an individual to provide collective goods voluntarily, if the individual economic gain from doing this is negative. However, the fact that larger groups actually do organize in local areas cannot be explained in strict economic terms. In an attempt to fill this gap in literature, we offer another solution, namely the presence of social incentives called "social capital". Social capital is derived from regular face-to-face, co-operative relations among larger groups in local areas. Such relations, we argue, are initiated by writing down formal "rules of the game", which are sanctioned effectively. This suggestion seems to be confirmed by empirical evidence from rural Denmark 1800-1900. During this period, written rules in the form of the formal founding statutes of co-operative associations enhanced informal peasant co-operation and stocks of beneficial social capital of an inclusive nature. As an outcome of this process, entrepreneurs voluntarily organized larger groups which provided collective goods locally, thus contributing to economic growth in former poor, rural areas.

Pourquoi l'entrepreneuriat est-il présent au sein de groupes assez importants? Cette question a posé problème aux sciences sociales depuis qu'Olson a montré, en 1965, qu'un individu n'a aucun intérêt à fournir des biens collectifs volontairement, si le bénéfice économique individuel qu'il en retire est négatif. Toutefois, le fait que des grands groupes s'organisent localement ne peut s'expliquer au sens strictement économique. Dans un effort pour combler cette lacune, nous offrons une autre solution, qui est l'existence d'incitants sociaux appelés "capital social". Le capital social provient d'un face-à-face régulier et de relations de coopération parmi des groupes assez larges à l'échelle locale. Nous soutenons que de telles relations se forment en consignant par écrit des "règles du jeu" formelles, qui sont effectivement sanctionnées. Notre suggestion semble confirmée par la preuve empirique que représente le Danemark rural de 1800-1900. Au cours de cette période, les règles écrites sous forme de statuts fondateurs officiels des coopératives ont renforcé la coopération paysanne informelle et les réserves en capital social positif, de nature inclusive. Par conséquent, les entrepreneurs ont organisé de façon délibérée des groupes assez importants, qui ont fourni des biens collectifs localement, et ont ainsi contribué à la croissance économique dans des zones rurales auparavant défavorisées.

\section{INDEX}

Keywords: social capital, entrepreneurship, rural poverty, formal and informal rules

Mots-clés: capital social, entrepreneuriat, pauvreté rurale, règles formelles et informelles 


\section{AUTHORS}

\section{GUNNAR L.H. SVENDSEN}

PhD student, Danish Institute of Border Region Studies, Aabenraa (Denmark), gs@ifg.dk

\section{GERT TINGGAARD SVENDSEN}

Associate professor, PhD, Department of Economics, Aarhus School of Business (Denmark), gts@asb.dk 